
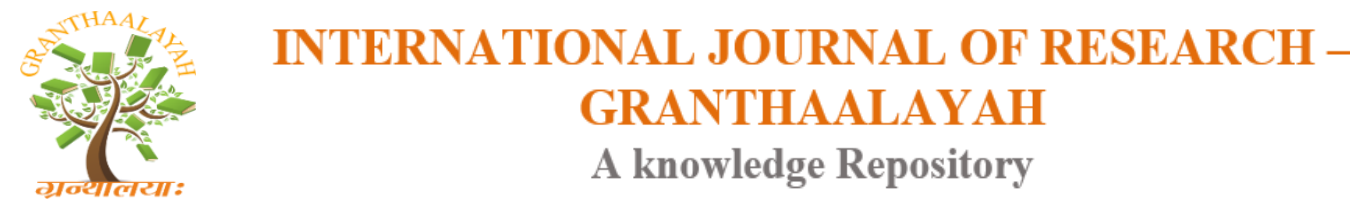

Social

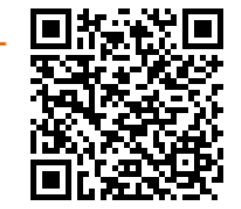

\title{
MOBILE LEARNING IN HIGHER EDUCATION
}

\author{
Ligi B *1, Dr B. William Dharma Raja ${ }^{2}$ \\ ${ }^{* 1}$ Ph.D Scholar, Manonmaniam Sundaranar University, Tirunelveli - 627 012, India \\ 2 Associate Professor \& Head, Department of Education, Manonmaniam Sundaranar University, \\ Tirunelveli - 627 012, India
}

DOI: https://doi.org/10.29121/granthaalayah.v5.i4(SE).2017.1942

\begin{abstract}
Mobile learning (m-learning) environments provides a wide range of new and exciting learning opportunities supported by the wireless technology. This paper discuss the role of m-learning in the new educational setting which creates student-centered learning and educational practice, offering new more flexible learning methods for higher education. In the digital 21 st century learning and educational processes are integrated with new information and communication technologies (ICTs) in the education system. This new m-learning technology has fascinated the interest of researchers, educators and companies developing learning system and instructional materials. M- Learning facilitates a new mechanism of teaching and learning process in order to enhance the learning and education experience of the students. The use of mobile devices and wireless technology in the new learning environments allows students to achieve more in their educational process. The students will be enthusiastic about the new learning options provided by the mobile technologies. The $\mathrm{m}$ - learning environment will provide new study opportunities for the students which strengthen the flexibility of being able to study at any time and any place.
\end{abstract}

Keywords: Mobile Learning; Wireless Technology; Higher Education.

Cite This Article: Ligi B, and Dr B. William Dharma Raja. (2017). "MOBILE LEARNING IN HIGHER EDUCATION." International Journal of Research - Granthaalayah, 5(4)SE, 1-6. https://doi.org/10.29121/granthaalayah.v5.i4(SE).2017.1942.

\section{Introduction}

Information and communication technologies (ICT) have become one of the most important factors for the development of society in the twenty-first century. Their impact is revolutionary. The development of e-Learning in education and training provides a way of new technologies in modern education and training systems. M- learning is more interactive, involves more contact, communication and collaboration with people. 
Mobile(M) learning is the ability to provide educational contents and resources on personal pocket devices such as smartphones, tablets, PDAs, i-pads, mobile phones etc., Educational content refers to digital learning resources which includes any form of content available on a personal device. M-learning is defined as learning multiple contexts, through social and content resources, using personal electronic devices.

M- learning is the use of mobile technology, either alone or in combination with other ICT, to enable learning anytime and anywhere at their own pace. The use of mobile technologies can help today's educators to embrace a truly learner centered approach to learning. Learning can reveal in a variety of ways: pupils can use mobile devices to access educational resources from various links, creates contents by themselves, connect with others to share the resources, both inside and outside classrooms. Sharing educational resources become instantaneous among everyone by using the same content, which leads to the instant feedback and instructions. Most of the students, researchers and educators view M- learning as the immediate successor of elearning.

Pinkwart et al. (2003) defined mobile learning as 'e-learning that uses mobile devices and wireless transmission'. Quinn (2000) defined it earlier, as simply learning that takes place with the help of mobile devices, or the intersection of mobile computing (the application of small, portable, and wireless computing and communication devices) and e-learning (learning facilitated and supported through the use of information and communications technology).

\section{Technologies in M-learning}

It is generally accepted that devices such as mobile phones, PDAs and MP3 players fit into the category of mobile devices (Andronico et al., 2003). However, laptop and notebook computers are sometimes not considered as mobile devices. "While they are capable of working without plugging into a power source and can utilize wireless networks, they are not devices that people can carry everywhere and quickly access at any time due to their size, configuration, and the time required to boot up and shut down" (Caudill, 2007).

\section{Wireless Networking}

Wireless Networking is the most significant features of mobile tools. When people are able to exchange relevant information at appropriate times, they can participate in a variety of community and collaborative situations that normally could not take place by distance. M-learning practitioners must consider providing mobile "media spaces" or computer mediated communications environments that will assist learners to communicate even they are physically and temporarily separated (Preece, 2002).

\section{Scope of M-Learning in Higher Education}

Institutions of higher education are always looking for effective teaching methods that place the student at the center of learning. Keeping this in mind, universities are increasingly exploiting technology in the teaching they provide. The use of technology in higher education is based on the interrelationships amongst at least three areas: technology, theories of learning and issues of 
educational practice. The increasing influence of globalization and the emerging information society, set new requirements for all areas of social life, including to higher education. MLearning became an important instrument in the new Higher Educational Environment in the digital age which creates student-centered learning and educational practice, offering new more flexible learning methods. It enables connections and collaborations between individual participants, and through their role as always-on, always-available, flexible personal communication devices. The focus on real problems of education and the uses of information and computer technology in the learning process is one of the most important factors in higher education.

\section{Factors influencing M- learning in education}

There are considerable numbers of factors that motivate learners and educators to use mobile applications in higher education. To successfully adopt M- learning, attention must be given to these influential factors. The mobile devices are utilized as the teaching and learning tools. The influential factors are classified into three main categories. The features of the devices, user's expectations and pedagogical advantage.

\section{Features of the Devices}

Features of the devices were further subcategorized into three aspects, namely: usability, functional and Privacy (Economides and Nikolaou, n.d.). Usability: From the usability aspect, M- learning tools are small, light, and portable (Ahonen, 2004; Cavus \& Ibrahim, 2009). These features make the learners feel at ease as learning is no longer constraints to the classroom with bulky backpacks containing piles of books and other learning materials. Such freedom makes the process of transmitting knowledge becomes flexible and can be carried out anytime and anywhere.

Functional: Functionally, the devices can provide instant and spontaneous. There are times when learners really need to get certain information fast. The devices will help the learners to quickly search such information. M-learning is a learning model that allows the learners to gain learning materials anywhere and anytime. To be able to continue with the learning without the constraints of time and location is an important element that affects how learners may be motivated to use their mobile applications (Lan \& Sie, 2010). Learners' access to information and learning material does not necessarily stop because of their location. Indeed learners can access and interact at various places and in a variety of situations.

Privacy : In comparing mobile devices with other computing devices (such as laptop and PC), it offers the learners a sense of privacy. Mobile applications provide the private virtual world to the learners that make them feel safe and motivated. Having a sense of privacy will provide many reasons for learners to interact with the device. The learners can access information and download independently from other learners (Moussa, 2003). 


\section{User's Expectations}

Researchers stress the importance of allowing learners to exercise more control over their own learning. The learners are more likely to attend to learning experiences if they are encouraged to take a more active role in their learning. M- learning opens up the opportunity for the learners to be at the center of the learning process, play an active role starting from determining their goal until the evaluation stage. Once they are actively engaged with the task, they are more likely to develop learning strategies that will aid their learning development, hence, contribute to their motivation. Unlike other digital media, a mobile device can be carried around all the time and gives its users great amount of control over how and when to access their mobile devices.

\section{Pedagogical Advantages}

Some of the pedagogical advantages in M-Learning are:

Flexible learning: High mobility of learners today makes flexible learning imperative. Mlearning opens up more opportunities for learning to take place regardless of place and time. The learners have the freedom to exist in different location than the teachers, to study at their own pace and time provided that they have the hardware and network infrastructure (Cavus and Al-Momani, 2011).

Collaborative learning: Social inclusion is the key to collaborative learning. The learners work together towards one common goal. Because of their accessibility, mobile devices support inclusion and allow for more opportunities for participation, and as a result, learning becomes more successful. Many researchers advocate the use of mobile technology that maximize learners' inclusion in the learning process

Blended learning: Blended learning which combines classroom instructions with $\mathrm{M}$ - learning can enhance and maximize the face-to-face and online methods. The learners can carry out their assignments and projects using $\mathrm{m}$-devices after a class session with their instructor.

Interactive learning: M-technologies also support interactive learning environment. The $\mathrm{m}$ - devices function as the interactive agents that allow varying levels of interactivity and engagement with the technology, thus enable the process of coming to know happens which indicates that the learning is taking place, discover and work with content that they determine to be necessary to solve the problem given by the teacher.

According to Attewell (2005), there are several uses inherent in m- learning: It helps learners to improve literacy and numeric skills, recognize their existing abilities and can be used for independent and collaborative learning experiences. It also helps learners to identify where they need assistance and support which helps to overcome the digital divide and helps to make learning informal. It helps learners to be more focused for longer periods. It helps to raise selfesteem and self-confidence and it is portable form one place to another. It is more wide spread and popular than Internet.

\section{Changes in Teaching and Learning}

Various changes in teaching and learning with m-learning explores the potential for collaborative learning, for increasing students' appreciation of their own learning process and for 
consolidation of learning, guiding students to see a subject differently than they would have done without the use of mobile devices, identifying learners' needs for just-in-time knowledge, exploring whether the time and task management facilities of m-devices can help students to manage their studies, reducing cultural and communication barriers between staff and students by using channels that students like; and wanting to know how wireless or m-technology alters attitudes, patterns of study and communication activity among students.

M-learning is widely used in schools, workplaces, cities and rural areas around the world. In comparison to traditional classroom pedagogical approaches, M-learning allows widened opportunities for timing, location, accessibility and context of learning. Wireless networked mdevices can enable learners to access relevant information when and where it is needed. Mlearners can travel to unique locations, physically with or virtually through their m-devices. The ability to access a variety of materials from anywhere at any time can provide multiple cues for comprehension and retention. Well implemented m-education can assist in the reduction of cognitive load for learner. Different patterns of presentation and amounts of information can potentially help learners to retain, retrieve, and transfer information when needed. Barker et al. (2005) described three significant impacts of m-technologies as "portability," "collaboration" and increased "motivation" of the learners. So, m-learning has the potential to change teaching and learning practices in higher education.

\section{Recommendations}

The educational institutions must take responsibility in sending a multimedia message to m-phones to trigger and motivate learners; the message should contain Web for related information by using hyperlinks; the contents and video lectures can be prepared and uploaded by the teachers; the students can discuss with their faculties as well as with their learning peers by text, voice, picture or video messaging; they can produce a digital story that tells what they learn through an audio or video lectures.

\section{References}

[1] Ahonen, M., Pehkonen, M., Syvanen, A., \& Turunen, H. (2004). M- learning and evaluation. Digital Learning 2 project working papers (Interim report). University of Tampere: Hypermedia Laboratory.

[2] Andronico, A., Carbonaro, A., Casadei, G., Colazzo, L., Molinari, A., and Ronchetti, M. (2003). Integrating a multi-agent recommendation system into a M- learning Management System. Artificial Intelligence in Mobile System Conference, 12 October, Seattle, WA.

[3] Attewell, J., \& Webster, T. (2005). Engaging and Supporting Mobile Learners. M- learning anytime everywhere: A book of papers from mLearn 2004, London: LSDA, 15-19.

[4] BenMoussa, C. (2003). Workers on the move: new opportunities through mobile commerce. Proceeding of the International Conference e-Society (IADIS), Lisbon, Portugal, 251-256.

[5] Caudill, J.G. (2007). The growth of m-learning and the growth of mobile computing: Parallel developments. International Review of Research in Open and Distance Learning, 8(2). http://www.irrodl.org/index.php/irrodl/article/view/348/913

[6] Cavus, N., \& Ibrahim, D. (2009). M-learning: an experiment in using SMS to support learning new English language words. British Journal of Educational Technology, 40(1), 78-91. 
[7] Economides, A.A., \& Nikolaou, N. (n.d.): Evaluation of handheld devices for M- learning. International Journal of Engineering Education (Forthcoming). Retrieved from http://www.conta.uom.gr/

[8] Golden, S. A. R. (2011). Strategy For Success Of Human Beings:-Time Management.

[9] Golden, S. A. R. (2016). RURAL STUDENTS' ATTITUDE TOWARDS ENGLISH AS MEDIUM OF INSTRUCTION IN HIGHER EDUCATION - AN ANALYSIS. International Journal of Research, 3(Special Issue - 16), 1-10.

[10] Golden, S. A. R. (2017). Attitude of Students and Teachers towards E- Learning - An Analysis. Recent Research in Social Science \& Humanities, 1, 5-10.

[11] Golden, S. A. R. (2017). Recent Research In Social Science \& Humanities.

[12] http://www.ascilite.org.au/conferences/brisbane05/blogs/proceedings/53_Mellow.pdf

[13] Lan, Y. F., \& Sie, Y. S. (2010). Using RSS to support M- learning based on media richness theory. Computers \& Education, 55(2), 723-732.

[14] Mellow, P. (2005). The Media Generation: Maximise learning by getting mobile. Retrieved from

[15] Preece, J. (2002). Online communities: designing usability, supporting sociability. Chichester:Wiley.

[16] Quinn, C. (2011). M- learning: Landscape and Trends. The ELearning Guild Research. Retrieved from http://www.elearningguild.com/showfile.cfm?id=434 4.

[17] Retrieved from http://w5.cs.uni- b.de/ krueger/aims2003/camera-ready/carbonaro-4.pdf 